\title{
TAX COMPLIANCE AND THE CHOICE OF AN OPTIMUM STRATEGY FOR THE ECONOMIC AGENTS
}

\author{
Vladimir A. Molodykh \\ North-Caucasus Federal University, Stavropol, Russian Federation \\ ORCID 0000-0001-9802-7356 \\ Andrey A. Rubezhnoy \\ North-Caucasus Federal University, Stavropol, Russian Federation \\ ORCID 0000-0001-5384-8599
}

\begin{abstract}
The strategy analysis of taxpayer behavior while observing tax law requires weakening of traditional initial assumptions in order to take into account the subjective character of economic agents' reaction to tax system changes. The aim of the given research is to identify the appropriate model of taxpayers' behavior in conditions of the tax control procedures transformation. The research methodology is based on the synthesis of the neo-classical concept of individual's rational choice, and on the assumptions of behavioral economics, which allowed considering the problem of tax evasion as the situation of social interaction among economic agents in decentralized system by taking into account their individual interests. The results of modeling demonstrated that tightening tax surveillance procedures undermines the coordination of interaction among autonomous tax groups. It leads to the growth of the possibility to select deviant behavior models. In this case the growth of tax management system efficiency expresses in budget income maximization, and is possible only by means of the extensive development of tax control procedures. The optimal strategy of the government behavior is using multimodal approach based on the partial replacement of control function for the cooperative strategy of tax subjects' interaction to reduce the natural taxpayer opportunism rate. And as an exceptional measure the harsh sanctions aimed to resist the deviant models of behavior are used. In this case the optimal choice for a taxpayer will depend additionally on the changes of social norms and stereotypes of behavior that characterize the quality of the institutional environment changes
\end{abstract}

\section{KEYWORDS}

Behavioral economy, tax compliance, tax evasion, tax policy

\section{HIGHLIGHTS}

1. Creation of the tax law observance models is necessary to recognize the existence of differentiated reaction to the actions of the state regarding the implementation of control functions. It demands weakening of the main assumptions of a rather rational behavior of economic agents

2. Prevalence of the rigid control function in the system of tax administration leads to the fact that this hierarchical system, which possesses the criterion function connected with maximizing the controllability of the system will never be able to increase the efficiency due to transition to a condition of decentralization

3. Change of tax control forms is possible based on introducing the procedures of "horizontal monitoring" of "a fair play of initiatives". It increases loyalty and trust by introducing the strategy of cooperation between taxpayers and the bodies of control 


\title{
СОБАЮАЕНИЕ НАЛОГОВОГО ЗАКОНОААТЕАЬСТВА И ВЫБОР ОПТИМААЬНОЙ СТРАТЕГИИ ПОВЕАЕНИЯ ЭКОНОМИЧЕСКИХ АГЕНТОВ
}

\author{
В. А. Молодых \\ Северо-Кавказский федеральный университет, г. Ставрополь, Россия \\ ORCID 0000-0001-9802-7356
}

\author{
А. А. Рубежной \\ Северо-Кавказский федеральный университет, г. Ставрополь, Россия \\ ORCID 0000-0001-5384-8599
}

\begin{abstract}
АННОТАЦИЯ
Анализ стратегий поведения налогоплательщиков в части соблюдения налоговой законодательства требует ослабления исходных классических допущений, чтобы учесть субъективный характер реакции экономических агентов на изменение налоговой системы. Целью исследования является определение оптимальной модели поведения налогоплательщиков в условиях трансформации процедур налогового контроля. Методология исследования основана на синтезе неоклассической концепции рационального выбора индивида и предпосылках поведенческой экономики, что позволило рассмотреть проблему уклонения от уплаты налогов как ситуацию социального взаимодействия экономических агентов в децентрализованной системе с учетом их индивидуальных интересов. Результаты моделирования показали, что ужесточение процедур налогового контроля отрицательно влияет на координацию взаимодействия автономных групп налогоплательщиков и приводит к росту вероятности выбора ими девиантных моделей поведения. В этом случае рост эффективности системы налогового администрирования, выраженный в максимизации доходов бюджета, возможен только за счет экстенсивного развития процедур налогового контроля. Оптимальной стратегией поведения государства является использование комбинированного подхода, который основан на частичной замене контрольной функции на кооперативную стратегию взаимодействия субъектов налоговой сферы для снижения естественного уровня оппортунизма налогоплательщиков, а в качестве исключительной меры используются жесткие санкции с целью противодействия девиантным моделям поведения. Тогда оптимальный выбор налогоплательщика будет дополнительно зависеть от изменения социальных норм и стереотипов поведения, которые характеризуют качество изменения институциональной среды
\end{abstract}

\section{КЛЮЧЕВЫЕ СЛОВА}

Поведенческая экономика, соблюдение налогового законодательства, уклонение от уплаты налогов, налоговая политика

\section{ОСНОВНЫЕ ПОЛОЖЕНИЯ}

1. Построение моделей соблюдения налогового законодательства с учетом дифференцированной реакции налогоплательщиков на действия государства в части реализации контрольных функций требует ослабления исходных классических допущений относительно рационального поведения экономических агентов

2. Доминирование в системе налогового администрирования контрольной функции приводит к тому, что данная иерархическая система, обладая целевой функцией, связанной с максимизацией контролируемости, не имеет возможности повышения своей эффективности за счет перехода в состояние децентрализации

3. Оптимизация форм налогового контроля возможна на основе внедрения процедур «горизонтального мониторинга» «фэйр-плей инициатив», повышения лояльности и доверия за счет внедрения стратегий сотрудничества налогоплательщиков и контрольных органов 


\section{Introduction}

The interest in studying the problem of tax evasion is connected with emergence of the first systematic theoretical analysis carried out by Allingham and Sandmo [1]. The main questions which were studied in detail further concern the problems of tax evasion extent measurement, explanation of taxpayers' behavior, identification of the factors influencing the choice of economic agents as it is possible to use the received conclusions and results in practice.

Despite great success in this direction, there are considerable gaps in understanding, explaining and controlling illegal taxpayers' behavior.

In the last decade there were works devoted to the use of experimental methods and theoretical prerequisites of behavioral economy to explain these separate phenomena. On one hand, it allows solving a problem of the lack of reliable information on observance by the taxpayer in legislation. Another interpretation of the received results demands the integration of "direct", "indirect" and "model" approaches and development of universal methods and models of taxpayers' behavior assessment, as well as the assessment of the tax administration operating system efficiency.

\section{The problems of economic agents' behavior modeling in the sphere of tax relations}

Originally the key issues of tax law observance were resolved within the frames of the neoclassical concept. It generally analyzed influences of the taxation and control parameters on a ratio of the declared and not declared (shadow) income. For example, possible strategies of the state behavior in the course of control activity implementation are analyzed by Kronshou and Alma [2]. In the received model the taxpayer does not possess full information on possible checks, and the state does not possess all information on the size of the hidden income. The received results demonstrate that the uncertainty of audit can lead to decrease in tax revenues and such type of behavior is counterproductive.

In general, the existing models allow considering the various aspects of a problem of tax evasion and improving tax discipline. For example, the analysis of the types of taxpayers' behavior (aggressive tax planning [3]), the ways of calculation and payment of taxes (the efficiency of the advanced system of tax payment [4]), expediency of tax control toughening mechanisms [5], the influence of centralization of the budgetary system level [6] is carried out.

There are two restrictive circumstances connected with theoretical and practical aspects of taxpayers' behavior modeling. First, the basic assumptions and prerequisites based on provisions of neoclassical school are too rigid, significantly simplifying real interaction of economic agents in the tax sphere. Secondly, inclusion of nonlinear communications considerably complicates the search of solutions of analytical models of tax evasion.

The main assumptions of rather rational behavior of economic agents which are also used in the analysis of taxpayers' behavior is the following:

1. It is supposed that the taxpayer acts as "homo economicus", i.e. has exclusively economic motivation, and its choice is described by maximizing function of usefulness which is presented in the form of net income. One of the early studies criticizing this prerequisite is the of work Alma and Torglera [7]. They come to the conclusions that the existing inaccuracy of behavior models of taxpayers relates to the fact that they do not behave as rational or selfish individuals. In decision-making process considerable impact is exerted by various aspects of "tax ethics" therefore the neoclassical paradigm cannot explain process of the choice of behavior model.

2. Evasion from the taxation in the form of removal of a part of the income to the shadow sphere is followed by certain expenses - transactional costs of evasion, which, as a rule, are not considered within neoclassical models.

3. In traditional neoclassical models of evasion the taxpayer necessarily acts 
in the conditions of absolute knowledge of parameters and conditions of taxation, evasion and control. This assumption that the taxpayer acts in the localized social network is too strong. As shown in the work [8] it is also necessary to consider the factor of socially oriented taxpayers' behavior.

4. It is implicit that all taxpayers are the hidden opportunists - carriers of the opportunistic motivation, who are withheld from concealment of income only by the economic unprofitability of tax evasion, and, in case of its efficiency, all taxpayers will transfer their whole income to the shadow sector. Therefore, taxpayers are considered to be potential criminals, which allows estimating the efficiency of a traditional paradigm of tax administration only, and does not give the chance to consider customer-oriented approaches [9].

Many researchers note that it is impossible to ignore the influence of institutional bases and standards of behavior in the analysis of tax law problems. Davies, Hekht and Perkins note that the existing social norms of behavior accepted in certain circles exert considerable impact on taxpayers' behavior. However, toughening of law-enforcement policy in case of considerable differentiation of society can lead to sharp violation of an equilibrium state, and the achievement of new balance will be followed by considerable additional costs [10]. De Juan and Lasheras confirm, using the example of the Spanish taxpayers, that they render a set of demographic, psychological and social factors (besides the probability of tax evasion fact detection and the sizes of penalties for decision-making), which can have crucial importance in general [11]. Frey and Torgler's research allows answering the question why so many people are ready to pay taxes, even in case when the probability of check and the sizes of tax penalties are small. The results of modeling carried out with the data of the poll in 30 countries of Eastern and Western Europe show the existence of high dependence between tendency to tax evasion and the tax morality, as well as the quality of the institutional environment [12].
Several researches prove that the total choice of taxpayers is influenced by such factors as religion [13], existence of sense of guilt and shame [14], quality of democratic institutes [15], change of tax ethics [16], and existence of the sense of patriotism [17].

Thus, creating the models of tax law observance, it is necessary to recognize that there are diverse types of tax behavior which differ in the differentiated reaction to the actions of the state regarding the control function implementation. It demands weakening of initial classical assumptions that the taxpayer's behavior became more various and adaptive.

The substantial assumptions of the model are:

1. The taxpayer has the exogenous income which it distributes on declared and shadow speaks rapidly by the rules depending on type of his behavior.

2. The declared and shadow income is assessed: the first - at the tax rate, the second is assessed at the rates of a tax and a penalty at evasion detection.

3. Concealment of the income is accompanied by emergence of additional transactional costs which are set in the form of constant standard coefficient to the shadow income.

4. The shadow income can be found as a result of check which happens to a certain probability, and at detection can be revealed in whole or in part. Thus, efficiency of control in model is considered by means of an extensive factor - the frequency of checks, and an intensive factor - effectiveness of check (a share of the found shadow income). Both factors are set as random variables.

5. Restrictions for the maximum and minimum shares of the shadow income which reflect degree of aggression of taxpayer behavior are introduced.

As a result we can consider tax evasion as necessary action of the taxpayer which can be is caused by exogenous shocks result of what there will be a transformation of system of tax administration regarding increase in its efficiency, first of all due to introducing the new softer tax control forms. 
The task of the maximum share of the shadow sector allows considering the level of law-abiding of taxpayers and scales of distribution of the hidden opportunism. Respectively, the less its value, the lower is the potential level of tax evasion, irrespective of economic efficiency of this kind of behavior. The minimum share of the hidden income characterizes tendency of taxpayers to opportunism and shows its "natural" level. It should be noted that this indicator indirectly characterizes quality of the institutional environment [12]. Also, it is necessary to consider a possibility of use of procedures of horizontal control as for decrease in "natural" level of opportunism, and its growth above average value.

Level of "natural" opportunism depends on various factors where an important role is played by the taxpayers' of justice assessment of tax system and its equivalence in terms of the public benefits provided by the state. Setting the minimum share of the hidden income, it is necessary to consider the fact that in society there is always a hidden opportunism which under certain conditions, providing its economic efficiency, can actively develop, and the opportunistic behavior becomes public standard and a stereotype of behavior.

\section{The Model of the taxpayer optimum strategy choice in the decentralized system}

Complexity of interaction of taxpayers with supervisory authorities is that the state has to constantly put certain pressure (implementation of control procedures) and at the same time is under reciprocal pressure (decrease in tax revenues due to use by taxpayers of deviant behavior models).

It is obvious that all set of taxpayers is the decentralized system. These systems are characterized by the fact that there is no uniform center of decision-making, so, decisions are made by each autonomous education separately (the natural or legal entity). It means that modeling of the decentralized systems, as a matter of fact, comes down to modeling of its separate elements. Aggregation of behavior of separate elements of system will also make the general model of functioning of the decentralized system.

Considering that taxpayers' pressure described above is collective action, in such system there is a problem connected this collective action happened presence of the taxpayers ready to tax evasion is necessary. In turn from outside the state is possible toughening of control procedures or introducing the new tax control forms based on cooperation. Anyway, a part of individuals decides to carry out collective action of $Z$, and the system in reply will increase the efficiency of $E_{s}$. At the same time the new condition of system and its level of efficiency is offered to all taxpayers, regardless of that, they evaded paying taxes or not. The formula is as follows:

$$
\begin{gathered}
E_{S}(Z) \rightarrow \text { max, } \\
Z=\sum_{i=1}^{n} z_{i}, \\
\max \left\{z_{i}\right\}<<Z .
\end{gathered}
$$

The state seeks to maximize the operating system of tax administration. For this purpose it has to provide appropriate level of control, and each taxpayer makes the decision on a possibility of tax evasion. At the same time individual pressure is much less than necessary collective pressure. The described situation has the appearance represented in the following payment matrix (Table 1).

Table 1

Payment matrix of taxpayers' pressure upon the state

\begin{tabular}{|l|c|c|}
\hline \multicolumn{1}{|c|}{ Index } & \multicolumn{1}{c|}{$\boldsymbol{Z}$} & $\mathbf{Z}^{*}$ \\
\hline Pressure & $h\left(E_{s}^{\prime}\right)-h\left(E_{s}\right)-z_{i}$ & $-z_{i}$ \\
\hline Not pressure & $h\left(E_{s}^{\prime}\right)-h\left(E_{s}\right)$ & 0 \\
\hline
\end{tabular}

Where $h\left(E_{s}^{\prime}\right)$ - benefit of the individual from the new level of system effectiveness; $\left(E_{s}\right)$ - benefit of the individual from the old level of system effectiveness.

The game shown above is a game with the nature in which the nature has two states: achievement of the set level of collective pressure $(Z)$ and not achievement of this level $\left(Z^{*}\right)$. At achievement of the 
set pressure level individuals can receive new benefits from system effectiveness expressed, for example, in granting tax benefits and decrease in a tax burden or introducing the new procedures of tax control ("horizontal monitoring" [18]).

The player's prize at strategy application "Pressure" and achievement of the set level of collective pressure is a difference between a benefit gain from change of system effectiveness $h\left(E_{s}^{\prime}\right)-h\left(E_{s}\right)$ and selling costs of the individual pressure $\left(z_{i}\right)$.

In case the taxpayer chose the strategy of "no-pressure" and at the same time the volume of under gathered taxes in the budgetary system reached critical level, then the individual receives the same gain of benefit from efficiency change, however at the same time it did not incur any costs.

If the individual chose strategy "Pressure", but at the same time the total volume of under gathered taxes in the budgetary system did not exceed critical level, then it, without getting anything, incurs transactional costs in connection with the choice of illegal behavior model, as well as potential penalties.

In case the individual chose the strategy of "no-pressure" and at the same time the set level of collective pressure was not reached, it gets nothing and loses nothing.

It is obvious that the strategy of "nopressure" is the dominating strategy. It is favorable to taxpayer to remain law-abiding, at the same time he has the right to expect with a certain probability that there can occur weakening of fiscal or administrative pressure when he receives benefit, without having incurred any costs. Similar strategy in literature carries the name of a problem of the free rider [19].

To get rid of this effect, it is necessary to transform the public benefit to other type of the benefits, for example, in the club benefit [20]. The club benefit bears in itself restriction for use of it only of those people who made the individual action. At the same time the property of the club benefits connected with lack of the competition in consumption remains same, as well as at the public benefits. It is possible to carry additional $20 \%$ to examples of the club benefits tax discounts which receive the organizations which are members of self-regulating cooperatives in France.

Having destroyed a possibility of receiving the benefit without commission of individual actions, we transform the initial situation described in Table 1 to a classical problem of game theory.

The individual is offered to participate in a game. The cost of a game is equal to $z_{i}$. With probability of $p(Z)$ the individual can receive a prize $C$.

The individual possessing the neutral attitude towards risk will meet the following condition:

$$
\begin{aligned}
M= & p(Z)\left[h\left(E_{s}^{\prime}\right)-h\left(E_{s}\right)-z_{i}\right]+ \\
& +(1-p(Z))\left(-z_{i}\right)>0,
\end{aligned}
$$

where $M-$ population mean of a game, $p(Z)$ - probability that $Z$ will be reached.

Having expressed from (1) probability that collective action will make $Z$, we receive the following expression:

$$
p(Z)>\frac{z_{i}}{h\left(E_{s}^{\prime}\right)-h\left(E_{s}\right)} .
$$

Expression (2) is a necessary condition of participation of the taxpayer in collective action $Z$ rather club benefits of $E_{s}$. From it is visible that the pressure level demanded from the individual is higher, the achievement of $Z$ has to have a high probability. At the same time, on the contrary, the benefits from a new condition of system effectiveness are higher; the achievement of $Z$ can have smaller probability in order that the taxpayer made the decision on realization of the individual pressure.

If specified in (2) ratio it is not carried out, but at the same time size $h\left(E_{s}^{\prime}\right)-h\left(E_{s}\right)$ is rather big, then the taxpayer can consider the possibility to participate in other game. A game is in reaching a desirable condition of system effectiveness only through the individual action, for example, through bribery to the staff of tax authorities. At the same time increase in system effectiveness will happen only for it. That is in this case the benefit becomes individual.

Besides the individual possessing the neutral attitude towards risk will make the following assessment of population mean: 


$$
\begin{aligned}
M= & p(b)\left[h\left(E_{s}^{\prime}\right)-h\left(E_{s}\right)-b\right]+ \\
& +(1-p(Z))(-b-c)>0,
\end{aligned}
$$

where $b$ - bribe size; $p(b)-$ probability to be not caught for bribery; c - punishment for bribery.

Having expressed from (3) probability to be not caught for bribery, we receive the following expression:

$$
p(Z)>\frac{b+c}{h\left(E_{s}^{\prime}\right)-h\left(E_{s}\right)-c} .
$$

At with, striving for infinity, and $b$ smaller what $h\left(E_{s}^{\prime}\right)-h\left(E_{s}\right)$, it turns out that the probability of $p(b)$ aspires to unit. That is for participation in this game "severity of laws has to be compensated by a non-obligation of their execution".

If for the taxpayer, conditions (2) and (4) are not carried out, then he refuses any attempts to increase system effectiveness with which interacts.

Distinctive feature of such projects is that the probability of successful fund raising, signatures, etc. is the dynamic size depending on the current level of the raised funds.

In relation to the situation with collective action described above the probability of achievement of the set level of pressure will have the following appearance:

$$
p\left(n z^{*}>Z\right)=S(Z)
$$

where $n$ - the number of the taxpayers who made at the moment individual action; $Z^{*}-$ the average amount of unpaid taxes; $S(Z)$ - value of function of survival of collective action to level $Z$.

\section{The solution to the problem of contradiction between taxpayers' individual actions and the efficiency of the decentralized system}

The problem described above concerns only the creation of the pressure mechanism to increase the efficiency of tax control procedures, however it also exists in the analysis of negative impact of illegal taxpayers' behavior in open systems taking into account tax morals. The matter is rather well opened in work [8]. Actually, taxpayers possess ambivalent characteristics, such as ideas of probability of check and detention, as well as about the choice of strategy of behavior by "the next taxpayers". In this case the level of tax law observance grows, in comparison with a situation when the strategies of neighbors' payments are unknown to the taxpayer.

Thus, the model of the choice of strategy of taxpayer behavior is also described by expression (2). And tendency to tax law observance will be higher in case of existence of the club benefit.

However, It should be noted that, inclusion of a possibility of holding new procedures of tax control such as "horizontal monitoring" and "initiative fair play", ("horizontal monitoring", "fairplay initiatives") in the conditions of the high level of tax morals leads to growth of transactional costs [18]. The following expenses concern to them:

- costs of internal audit for the purpose of restriction of access for unfair taxpayers for the accession to self-regulatory organizations, otherwise, it is costs of fight against $C_{f}$;

- costs of coordination of taxpayers $\left(C_{Z}\right)$, they have to agree about a target indicator $(Z)$ and about the level of individual influence $\left(z_{i}\right)$.

It means that expression (2) will take the following form:

$$
\begin{aligned}
M= & p(Z)\left[h\left(E_{s}^{\prime}\right)-h\left(E_{s}\right)-z_{i}-C_{f i}-C_{z i}\right]+ \\
& +(1-p(Z))\left(-z_{i}-C_{f i}-C_{z i}\right)>0,
\end{aligned}
$$

where $C_{f}-$ costs of fight against "free riders" counting on 1 individual; $C_{z i}-$ costs of coordination counting on 1 individual.

If from (5) to express probability of achievement of $Z$ again, then the following expression will turn out:

$$
p(Z)>\frac{z_{i}+C_{f i}+C_{z i}}{h\left(E_{s}^{\prime}\right)-h\left(E_{s}\right)} .
$$

From (6) it is visible that increased requirements are imposed to probability of achievement of $Z$ and to a benefit gain from a new condition of efficiency now. As a result of it many participants will count, it does not make sense that to participate in this game. If transactional costs have considerable level, then it can lead to the fact that the decentralized system will not be able effectively to create and consume both the public, and club benefits. 
Having expressed from (6) size of transactional costs, we will receive the restriction for their sum necessary for participation of the individual in collective action:

$$
C_{f i}-C_{z i}<p(Z)\left[h\left(E_{s}^{\prime}\right)-h\left(E_{s}\right)\right]-z_{i} .
$$

Transaction costs counting on 1 taxpayer have to be less, than the work of probability of achievement of $Z$ and gain of benefit from growth of system effectiveness minus the size of individual pressure.

At outflow of individuals from the decentralized system in it the costs connected with coordination decrease. However, at the same time also the probability of achievement of $Z$ as the potential number of participants decreases, so, the individual contribution of the individual of $z_{i}$ raises. Therefore, the decentralized system will have the right for life only if:

$$
\frac{d C_{z i}}{d N_{d}}=\frac{d p(Z)}{d N_{d}}\left[h\left(E_{s}^{\prime}\right)-h\left(E_{s}\right)\right],
$$

where $N_{d}$ - the number of individuals in the decentralized system.

If the condition (7) is not satisfied, then in the considered environment there is only one system which is hierarchical. If the condition is satisfied, then the overflow of individuals in hierarchical system comes from the decentralized system until, optimum $N_{d}$ value at which, on the one hand, there are rather low transaction costs will not be reached yet, on the other hand, there is enough people for achievement of the set level Z. In other words, such $N_{d}$ at which in a condition (7) there is an equality of the left and right part is necessary.

Proceeding from the aforesaid, it is possible to draw a conclusion that an environment $O$ can be described in the form of couple of values $\{\alpha ; 1-\alpha\}$ where $\alpha$ there is a share of the taxpayers using the decentralized system, and 1- $\alpha$ there is a share of the taxpayers using hierarchical system.

Provided that the hierarchical system is such a system, where the top level has the criterion of the function directed to maximizing efficiency, a couple of values $\{\alpha ; 1-\alpha\}$ will be optimum. If the hierarchical system is a system, where top levels of hierarchy have the criterion of the function connected with maximizing control- lability of system, then the couple of values $\{\alpha ; 1-\alpha\}$ can differ from optimum. It is the fact that top levels of hierarchy to increase the control will seek to limit an overflow from hierarchical system in the decentralized system, as it will reduce their level of control.

From this a conclusion follows that a prevalence in system of tax administration of rigid control function and ignoring of such factors as trust to the operating tax system, existence of tax morals leads to the fact that this hierarchical system, possessing the criterion function connected with maximizing controllability of system will never be able to increase the efficiency due to transition to a condition of decentralization.

\section{Conclusions}

In the long term the increase in the systematic effectiveness of tax administration is possible due to the growth of entropy of the tax system top levels, reduction of uncertainty in the tax sphere, lifting of restrictions forming an imbalance of relationship between the state and taxpayers.

The first two options demand considerable investments. Increase in entropy of top levels of hierarchy requires the creation of additional divisions in tax authorities, increase in number of qualified personnel in the sphere of tax conflicts solution. Reduction of uncertainty demands introduces the new informational and analytical systems of decision-making support.

The third option is potentially the least expensive. The change of the right part of the restriction in the smaller party, under the law of hierarchical compensations by Sedov [21], will mean that the top level of hierarchy weakens functions of control and management and undertakes functions on coordination of the self-organized organizations created as a result of growth of entropy various autonomous. The change of tax control forms, introducing the procedures of "horizontal monitoring" of "a fair play of initiatives", increases loyalty and trust due to introducing the strategy of cooperation of taxpayers and bodies of control, and can be the purpose of such coordination. 


\section{Acknowledgments}

Work was prepared with financial support of the Russian Foundation for Basic Research (RFBR) (project No. 17-32-01024/17)

\section{Благодарности}

Исследование выполнено при финансовой поддержке Российского фонда фундаментальных исследований (РФФИ) (проект № 17-32-01024/17)

\section{References}

1. Allingham M. G., Sandmo A. Income Tax Evasion: A Theoretical Analysis. Journal of Public Economics, 1972, vol. 1, no. 3-4, pp. 323-338. DOI: 10.1016/0047-2727(72)90010-2.

2. Cronshaw M. B., Alm J. Tax Compliance with 2-sided Uncertainty. Public Finance Quarterly, 1995, vol. 23, no. 2, pp. 139-166.

3. Erard B. Taxation with Representation - an Analysis of the Role of Tax Practitioners in Tax Compliance. Journal of Public Economics, 1993, vol. 52, no. 2, pp. 163-197.

4. Yaniv G. Tax Compliance and Advance Tax Payments: A Prospect Theory Analysis. $\mathrm{Na-}$ tional Tax Journal, 1999, vol. 52, no. 4, pp. 753-764.

5. Murphy K. The Role of Trust in Nurturing Compliance: A Study of Accused Tax Avoiders. Law and Human Behavior, 2004, vol. 28, no. 2, pp. 187-209.

6. Doerrenberg P., Peichl A. Progressive Taxation and Tax Morale. Public Choice, 2013, vol. 155, no. 3-4, pp. 293-316.

7. Alm J., Torgler B. Do Ethics Matter? Tax Compliance and Morality. Journal of Business Ethics, 2011, vol. 101, no. 4, pp. 635-651.

8. Korobow A., Johnson C., Axtell R. An Agent-Based Model of Tax Compliance with Social Networks. National Tax Journal, 2007, vol. 60, no. 3, pp. 589-610.

9. Alm J., Cherry T., Jones M., McKee M. Taxpayer Information Assistance Services and Tax Compliance Behavior. Journal of Economic Psychology, 2010, vol. 31, no. 4, pp. 577-586.

10. Dejuan A., Lasheras N. A., Mayo R. Voluntary Lax Compliant Behavior of Spanish Income-Tax Payers. Public Finance = Finances publiques, 1994, vol. 49, pp. 90-105.

11. Davis J. S., Hecht G., Perkins J. D. Social Behaviors, Enforcement, and Tax Compliance Dynamics. Accounting Review, 2003, vol. 78, no. 1, pp. 39-69.

12. Frey B. S., Torgler B. Tax Morale and Conditional Cooperation. Journal of Comparative Economics, 2007, vol. 35, no. 1, pp. 136-159.

13. Torgler B. The Importance of Faith: Tax Morale and Religiosity. Journal of Economic Behavior E Organi Qation, 2006, vol. 61, no. 1, pp. 81-109.

14. Erard B., Feinstein J. S. The Role of Moral Sentiments and Audit Perceptions in Tax Compliance. Public Finance = Finances publiques, 1994, vol. 49, pp. 70-89.

15. Pommerehne W. W., Hart A., Frey B. S. Tax Morale, Tax Evasion and the Choice of Policy Instruments in Different Political-Systems. Public Finance = Finances publiques, 1994, vol. 49, pp. 52-69.

16. WenQel M. Misperceptions of Social Norms about Tax Compliance: From Theory to Intervention. Journal of Economic Psychology, 2005, vol. 26, no. 6, pp. 862-883.

17. Konrad K. A., Qari S. The Last Refuge of a Scoundrel? Patriotism and Tax Compliance. Economica, 2012, vol. 79, no. 315, pp. 516-533.

18. Kirchler E., Kogler C., Muehlbacher S. Cooperative Tax Compliance From Deterrence to Deference. Current Directions in Psychological Science, 2014, vol. 23, no. 2, pp. 87-92.

19. Auzan A. Institutsionalnaya ekonomika [Institutional Economy]. Moscow, INFRA-M Publ., 2005. 415 p.

20. Buchanan J. An Economic Theory of Clubs. Economica, 1965, vol. 125, pp. 208-221.

21. Sedov E. Information and Entropy Properties of Social Systems. ONS, 1993, no. 5, pp. 92-100.

\section{Authors}

Molodykh Vladimir A. - PhD in Economics, Associate Professor, Department of Tax Policy and Custom, North-Caucasus Federal University, Stavropol, Russian Federation (1 Pushkin St., 355009, Stavropol, Russian Federation); ORCID 0000-0001-9802-7356; e-mail: v.a.molodyh@yandex.ru 
Rubezhnoy Andrey A. - PhD in Economics, Associate Professor, Department of Tax Policy and Custom, North-Caucasus Federal University, Stavropol, Russian Federation (1 Pushkin St., 355009, Stavropol, Russian Federation); ORCID 0000-0001-5384-8599; e-mail: aaru@inbox.ru

\section{Информация об авторах}

Молодых Владимир Анатольевич - кандидат экономических наук, доцент, кафедра налоговой политики и таможенного дела, Северо-Кавказский федеральный университет, г. Ставрополь, Россия (355009, Ставропольский край, г. Ставрополь, Пушкина, 1); ORCID 0000-0001-9802-7356; e-mail: v.a.molodyh@yandex.ru Рубежной Андрей Александрович - кандидат экономических наук, доцент, кафедра налоговой политики и таможенного дела, Северо-Кавказский федеральный университет, г. Ставрополь, Россия (355009, Ставропольский край, г. Ставрополь, Пушкина, 1); ORCID 0000-0001-5384-8599; e-mail: aaru@inbox.ru

\section{For citation}

Molodykh V. A., Rubezhnoy A. A. Tax Compliance and the Choice of an Optimum Strategy for the Economic Agents. Journal of Tax Reform, 2017, vol. 3, no. 3, pp. 216-225. DOI: $10.15826 /$ itr.2017.3.3.041

\section{Аия цитирования}

Молодых В. А. Соблюдение налогового законодательства и выбор оптимальной стратегии поведения экономических агентов / В. А. Молодых, А. А. Рубежной // Journal of Tax Reform. - 2017. - T. 3, № 3. - C. 216-225. - DOI: $\underline{10.15826 /}$ itr.2017.3.3.041

\section{Article info}

Received October 30, 2017; accepted December 1, 2017

\section{Информация о статье}

Дата поступления 30 октября 2017 г.; дата принятия к печати 1 декабря 2017 2. 